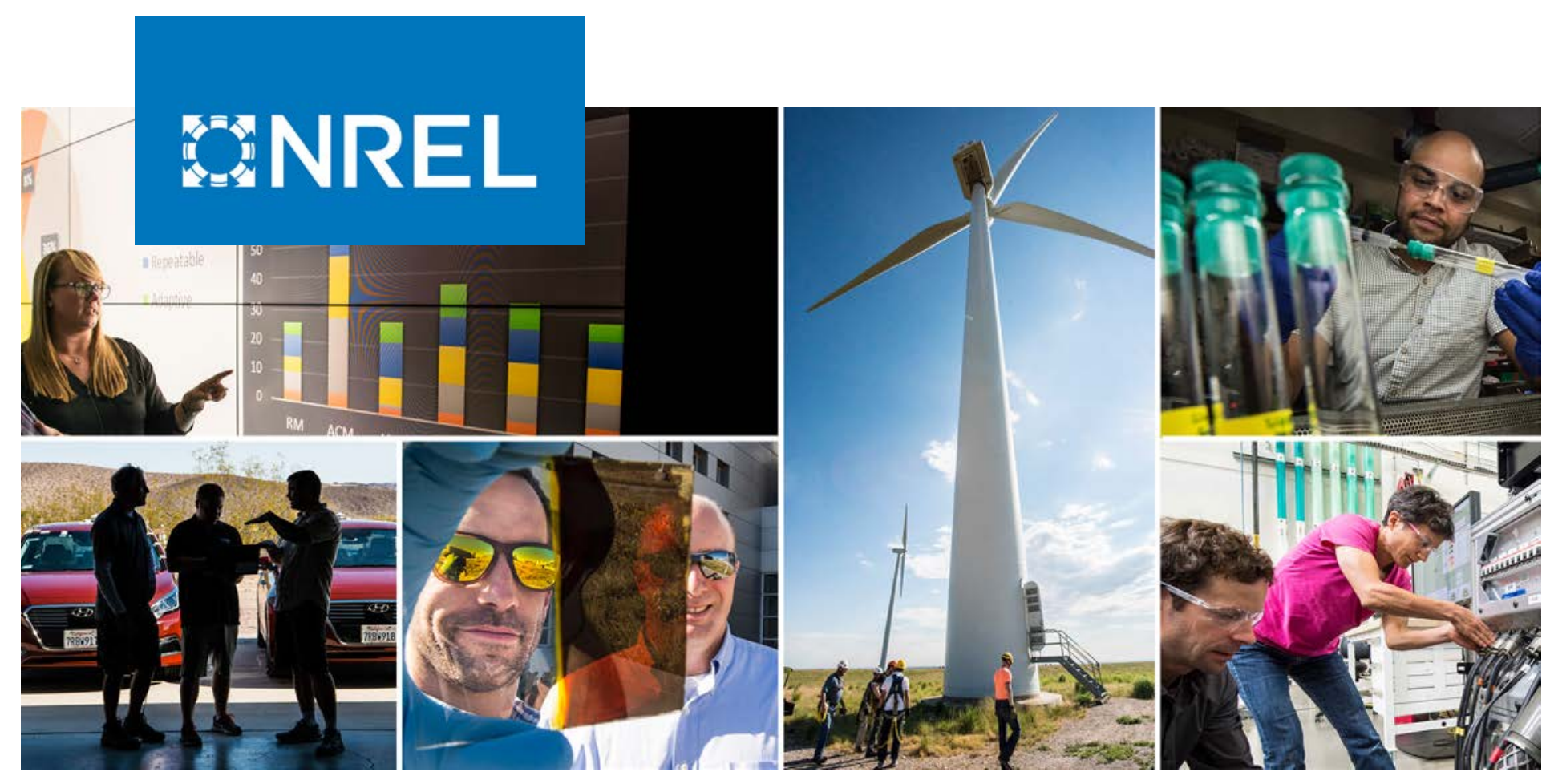

\title{
Assessment of BQ-9000 Biodiesel Properties for 2018
}

\author{
Teresa L. Alleman
}

National Renewable Energy Laboratory

Produced under direction of the National Biodiesel Board by the National Renewable Energy Laboratory (NREL) under CRADA agreement number CRD-15-593.

NREL is a national laboratory of the U.S. Department of Energy Office of Energy Efficiency \& Renewable Energy

Operated by the Alliance for Sustainable Energy, LLC

This report is available at no cost from the National Renewable Energy Laboratory (NREL) at www.nrel.gov/publications.
Strategic Partnership Project Report NREL/TP-5400-75796

January 2020 


\title{
GNREL
}

\section{Assessment of BQ-9000 Biodiesel Properties for 2018}

\author{
Teresa L. Alleman
}

National Renewable Energy Laboratory

\section{Suggested Citation}

Alleman, Teresa L. 2020. Assessment of BQ-9000 Biodiesel Properties for 2018.

Golden, CO: National Renewable Energy Laboratory. NREL/TP-5400-75796.

https://www.nrel.gov/docs/fy20osti/75796.pdf.

NREL is a national laboratory of the U.S. Department of Energy Office of Energy Efficiency \& Renewable Energy Operated by the Alliance for Sustainable Energy, LLC

This report is available at no cost from the National Renewable Energy Laboratory (NREL) at www.nrel.gov/publications.

Contract No. DE-AC36-08GO28308
Strategic Partnership Project Report NREL/TP-5400-75796 January 2020

National Renewable Energy Laboratory 15013 Denver West Parkway Golden, CO 80401 303-275-3000 • www.nrel.gov 


\section{NOTICE}

This work was authored by the National Renewable Energy Laboratory, operated by Alliance for Sustainable Energy, LLC, for the U.S. Department of Energy (DOE) under Contract No. DE-AC36-08G028308. Support for the work was also provided by the National Biodiesel Board under CRADA agreement number CRD-15-593. The views expressed in the article do not necessarily represent the views of the DOE or the U.S. Government. The U.S. Government retains and the publisher, by accepting the article for publication, acknowledges that the U.S. Government retains a nonexclusive, paid-up, irrevocable, worldwide license to publish or reproduce the published form of this work, or allow others to do so, for U.S. Government purposes.

This report is available at no cost from the National Renewable Energy Laboratory (NREL) at www.nrel.gov/publications.

U.S. Department of Energy (DOE) reports produced after 1991 and a growing number of pre-1991 documents are available free via www.OSTI.gov.

Cover Photos by Dennis Schroeder: (clockwise, left to right) NREL 51934, NREL 45897, NREL 42160, NREL 45891, NREL 48097, NREL 46526.

NREL prints on paper that contains recycled content. 


\section{Acknowledgments}

The author wishes to thank the National Biodiesel Board for funding support for this work under Cooperative Research and Development Agreement CRD-15-593. Technical support was provided by Mr. Steve Howell of M4 Consulting, Mr. Scott Fenwick of the National Biodiesel Board, and Dr. Richard Nelson of Enersol Resources. 


\section{List of Acronyms}

ASTM

B100

CSFT

NREL
ASTM International

neat ( $100 \%$ by volume) biodiesel

cold soak filterability test

National Renewable Energy Laboratory 


\section{Executive Summary}

This is the second in a series of reports on the annual quality of neat biodiesel (B100). This report covers biodiesel produced and sold in the United States in calendar year 2018. The B100 was produced by companies that participate in the industry's voluntary quality program, BQ9000. Each company agreed to participate by providing monthly quality data to a third-party group of industry experts who removed all identifying information and randomized the data prior to providing the data to the National Renewable Energy Laboratory (NREL) for statistical analysis. This report covers biodiesel produced in calendar year 2018 and the quality parameters assessed are listed below:

- $\quad$ Sodium and potassium $(\mathrm{Na}+\mathrm{K})$

- Calcium and magnesium $(\mathrm{Ca}+\mathrm{Mg})$

- Phosphorus (P)

- Flash point or alcohol control

- Water and sediment

- Cloud point (CP)

- Acid number

- Free glycerin

- Total glycerin

- Monoglycerides

- Sulfur

- Oxidation stability

- Visual appearance

- Cold soak filterability test (CSFT).

The results are summarized in Table ES-1. 
Table ES-1. BQ-9000 Critical Parameter Summary Table, Calendar Year 2018

\begin{tabular}{|c|c|c|c|c|c|c|c|}
\hline $\begin{array}{l}\text { BQ-9000 } \\
\text { Parameter }\end{array}$ & $\begin{array}{c}\text { \# of } \\
\text { Values } \\
\text { Reported }\end{array}$ & Minimum & Maximum & Average & Median & $\begin{array}{l}\text { Standard } \\
\text { Deviation }\end{array}$ & $\begin{array}{c}95^{\text {th }} \\
\text { Percentile }\end{array}$ \\
\hline $\mathrm{Na}+\mathrm{K}, \mathrm{ppm}$ & 431 & 0 & 4.5 & 0.688 & 0.412 & 0.784 & 2.20 \\
\hline $\mathrm{Ca}+\mathrm{Mg}, \mathrm{ppm}$ & 426 & 0 & 4.4 & 0.313 & 0.079 & 0.579 & 2.00 \\
\hline $\mathrm{P}, \mathrm{ppm}$ & 383 & 0 & 10 & 0.371 & 0 & 1.74 & 0.98 \\
\hline Flash Point, ${ }^{\circ} \mathrm{C}$ & 413 & 89 & 193 & 153 & 161 & 25 & 183 \\
\hline $\begin{array}{c}\text { Alcohol Control, } \\
\text { mass } \%\end{array}$ & 175 & 0 & 0.192 & 0.066 & 0.060 & 0.045 & 0.141 \\
\hline $\begin{array}{c}\text { Water and } \\
\text { Sediment, vol\% }\end{array}$ & 332 & 0 & 0.035 & 0.002 & 0.00 & 0.004 & 0.010 \\
\hline Cloud Point, ${ }^{\circ} \mathrm{C}$ & 453 & -5.6 & 17 & 1 & 0 & 3.7 & 8.8 \\
\hline $\begin{array}{l}\text { Acid Number, mg } \\
\mathrm{KOH} / \mathrm{g}\end{array}$ & 453 & 0.02 & 0.51 & 0.27 & 0.27 & 0.106 & 0.43 \\
\hline $\begin{array}{l}\text { Free Glycerin, } \\
\text { mass } \%\end{array}$ & 453 & 0 & 0.030 & 0.006 & 0.005 & 0.004 & 0.014 \\
\hline $\begin{array}{l}\text { Total Glycerin, } \\
\text { mass } \%\end{array}$ & 453 & 0.005 & 0.225 & 0.093 & 0.099 & 0.045 & 0.164 \\
\hline $\begin{array}{c}\text { Monoglycerides, } \\
\text { mass } \%\end{array}$ & 453 & 0 & 0.642 & 0.269 & 0.288 & 0.130 & 0.474 \\
\hline Sulfur, ppm & 448 & 0 & 14 & 3.4 & 2.0 & 3.6 & 10.9 \\
\hline $\begin{array}{l}\text { Oxidation } \\
\text { Stability, hr. }\end{array}$ & 452 & 4.4 & 27.5 & 9.5 & 8.7 & 3.4 & 14.2 \\
\hline $\begin{array}{c}\text { Cold Soak } \\
\text { Filterability Test, } \\
\text { sec }\end{array}$ & 441 & 66 & 338 & 104 & 100 & 28 & 144 \\
\hline
\end{tabular}




\section{Table of Contents}

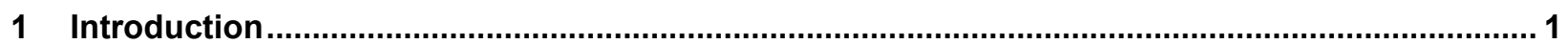

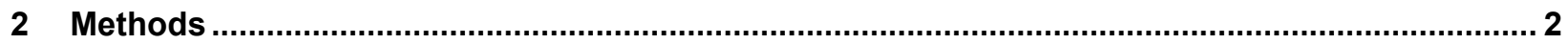

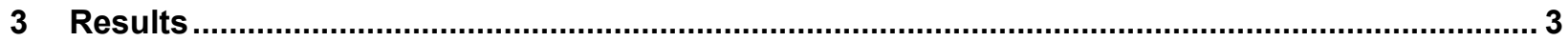

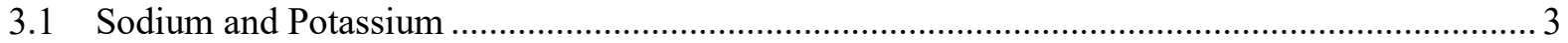

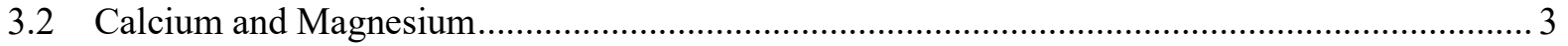

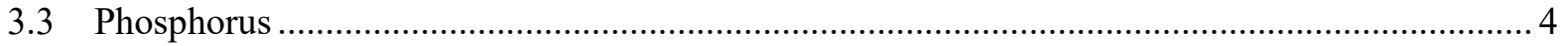

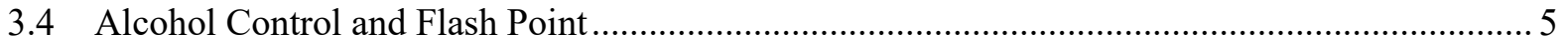

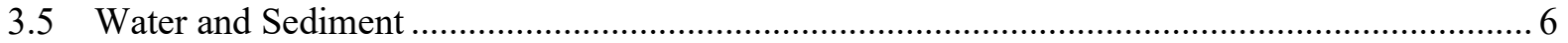

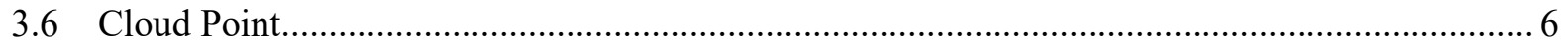

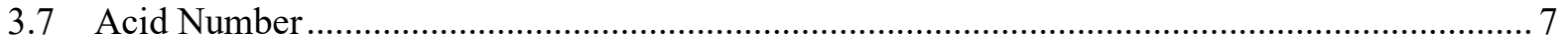

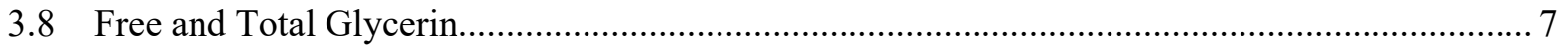

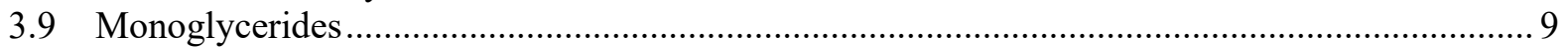

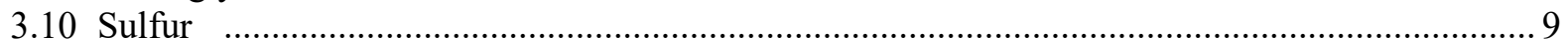

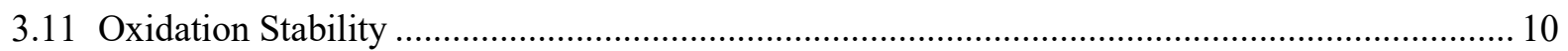

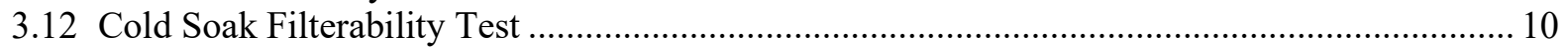

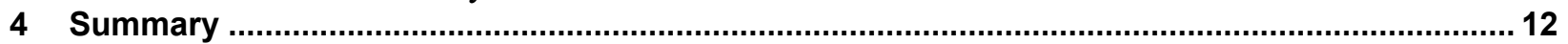

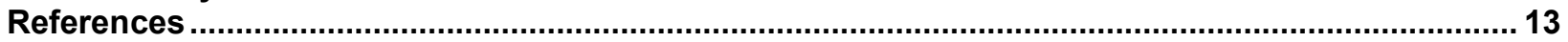

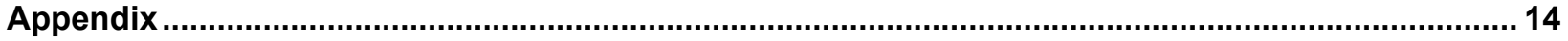




\section{List of Figures}

Figure 1. Sodium and potassium content of biodiesel samples, January-December 2018....................... 3

Figure 2. Calcium and magnesium content for biodiesel samples, January-December 2018 .................... 4

Figure 3. Phosphorus content for biodiesel samples, January-December 2018 ....................................... 4

Figure 4. Flash point for biodiesel samples, January-December 2018 ............................................... 5

Figure 5. Methanol content for biodiesel samples, January-December 2018 ...................................... 5

Figure 6. Water and sediment for biodiesel samples, January-December 2018 ................................. 6

Figure 7. Cloud point for biodiesel samples, January-December 2018 ........................................... 6

Figure 8. Acid number for biodiesel samples, January-December 2018 ........................................... 7

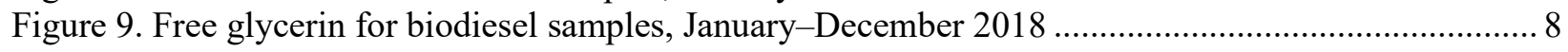

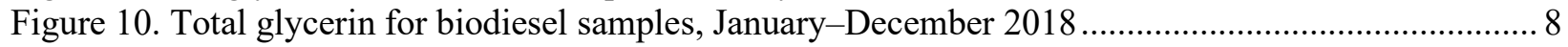

Figure 11. Monoglyceride content for biodiesel samples, January-December 2018 .............................. 9

Figure 12. Sulfur content for biodiesel samples, January-December 2018 ….................................... 9

Figure 13. Oxidation stability for biodiesel samples, January-December 2018 .................................... 10

Figure 14. CSFT for biodiesel samples, January-December 2018 ..................................................... 11

Figure A-1. All data analysis of sodium and potassium for B100 samples produced

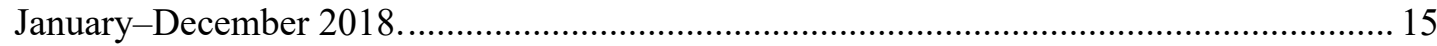

Figure A-2. All data analysis of calcium and magnesium for B100 samples produced

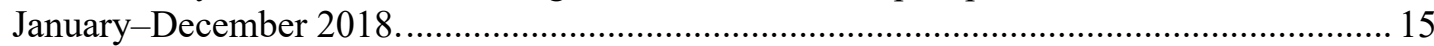

Figure A-3. All data analysis of phosphorus for B100 samples produced January-December 2018........ 16

Figure A-4. All data analysis of flash point for B100 samples produced January-December 2018 ......... 16

Figure A-5. All data analysis of alcohol control for B100 samples produced January-December 2018.. 17

Figure A-6. All data analysis of water and sediment for B100 samples produced January-December 2018 .......................................................................................... 17

Figure A-7. All data analysis of cloud point for B100 samples produced January-December 2018........ 18

Figure A-8. All data analysis of acid number for B100 samples produced January-December 2018. ..... 18

Figure A-9. All data analysis of free glycerin for B100 samples produced January-December 2018 ...... 19

Figure A-10. All data analysis of total glycerin for B100 samples produced January-December 2018 ... 19

Figure A-11. All data analysis of monoglycerides for B100 samples produced January-December

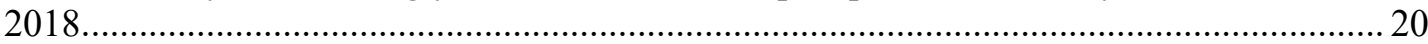

Figure A-12. All data analysis of sulfur for B100 samples produced January-December 2018.............. 20

Figure A-13. All data analysis of oxidation stability for B100 samples produced January-December

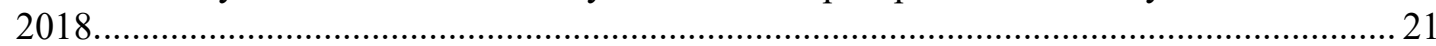

Figure A-14. All data analysis of CSFT for B100 samples produced January-December 2018.............. 21

\section{List of Tables}

Table ES-1. BQ-9000 Critical Parameter Summary Table, Calendar Year 2018 .....................................vi

Table 1. BQ-9000 Critical Parameter Summary Table, Calendar Year 2018 .......................................... 12 


\section{Introduction}

We previously reported on the quality of neat biodiesel (B100) for calendar year 2017 (Alleman 2020 ) with the intent of continuing to do so annually. The National Renewable Energy Laboratory (NREL)'s continued collaboration with biodiesel industry experts was critical to acquiring monthly quality data for this second report. The goal was to gather and analyze data from companies that participate in the voluntary industry quality program, BQ-9000. This report is the second in an ongoing series that summarizes biodiesel quality produced and sold in the United States. A similar report produced by Association Quality Management of Germany (AGQM) is available for German-produced biodiesel (Dietrich 2017). That report covered 1,060 data points from 53 biodiesel samples.

The following critical fuel quality parameters for U.S. biodiesel were assessed: sodium and potassium $(\mathrm{Na}+\mathrm{K})$, calcium and magnesium $(\mathrm{Ca}+\mathrm{Mg})$, phosphorus $(\mathrm{P})$, flash point or alcohol control, water and sediment, cloud point, acid number, free glycerin, total glycerin, monoglycerides, sulfur (S), oxidation stability, visual appearance, and cold soak filterability test (CSFT). The analysis included 5,391 data points for calendar year 2018. 


\section{Methods}

Data analyzed in this report were provided by the third-party team of Mr. Scott Fenwick of the National Biodiesel Board (NBB), Mr. Steve Howell of M4 Consulting, and Dr. Richard Nelson of Enersol Resources. The team requested monthly analytical quality data from producers participating in the BQ-9000 quality program (additional discussion of the BQ-9000 program and data methods can be found in the report for calendar year 2017 [Alleman 2020]). Upon agreeing to participate, producers sent monthly production data to the third-party team.

Identifying information, such as plant name, location, and lot production date were removed by the third-party team. The dataset was randomized on a parameter-by-parameter basis and provided to NREL for analysis. The same statistical analysis was conducted, including average, minimum and maximum value, median, and $95^{\text {th }}$ percentile.

The data analysis was conducted in the same manner as the calendar year 2017 analysis. Values provided fell into one of two categories: actual data were provided and discussed in the body of this report, or data was provided as "less than" or "greater than" a particular value. For example, if CSFT data were provided as " $<360$ seconds," the data were removed from the primary analysis. A secondary analysis, included in the appendix for informational purposes only, assumed the "less than" or "greater than" sign could be removed and the remaining value used. As an example, a flash point reported as " $>130^{\circ} \mathrm{C}$ " was assumed to be $130^{\circ} \mathrm{C}$ for the appendix analysis. 


\section{Results}

For test method details, the significance of the test parameters, and specification limits, see for example ASTM International (ASTM) D6751, Standard Specification for Biodiesel Fuel Blend Stock (B100) for Middle Distillate Fuels. There were no changes in the referee methods, or the alternate test methods between 2017 and 2018. Details of the referee and alternate methods can be found in this report for 2017 (Alleman 2020).

\subsection{Sodium and Potassium}

The average $\mathrm{Na}+\mathrm{K}$ for the 2018 samples was 0.69 parts per million (ppm) (Figure 1). The $95^{\text {th }}$ percentile of the data was $2.20 \mathrm{ppm}$ and the median was $0.42 \mathrm{ppm}$.

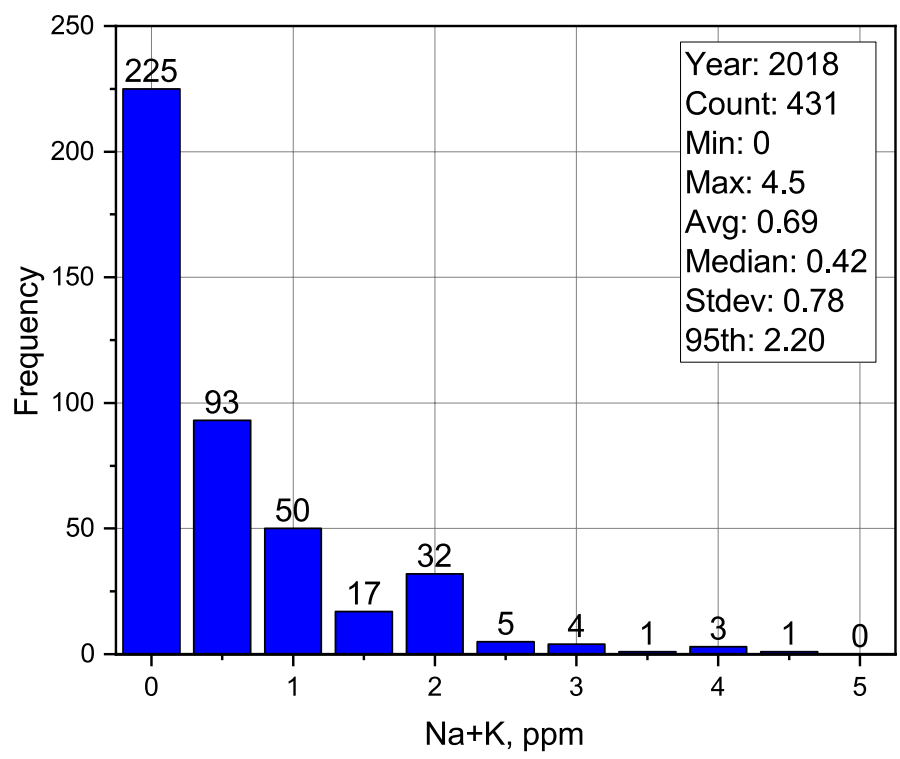

Figure 1. Sodium and potassium content of biodiesel samples, January-December 2018

\subsection{Calcium and Magnesium}

Figure 2 shows the $\mathrm{Ca}+\mathrm{Mg}$ results from the 2018 samples, with an average of $0.31 \mathrm{ppm}$ and a median of $0.08 \mathrm{ppm}$. The $95^{\text {th }}$ percentile was $2.00 \mathrm{ppm}$. 


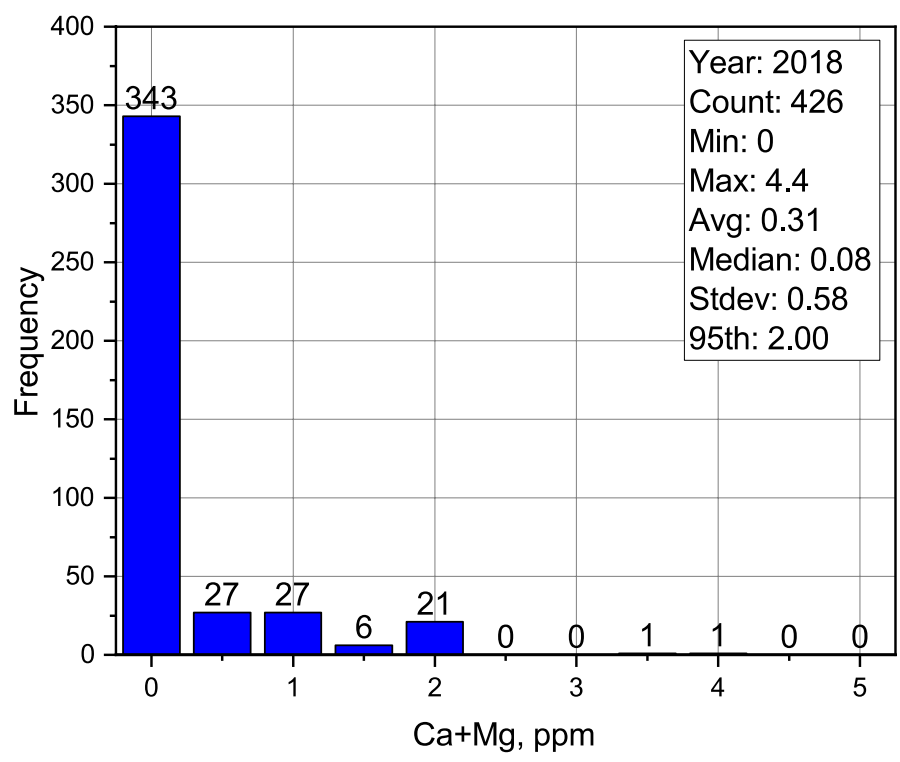

Figure 2. Calcium and magnesium content for biodiesel samples, January-December 2018

\subsection{Phosphorus}

The 2018 average $\mathrm{P}$ content was $0.371 \mathrm{ppm}$, with a median value of $0 \mathrm{ppm}$ (Figure 3 ). The $95^{\text {th }}$ percentile was $0.98 \mathrm{ppm}$.

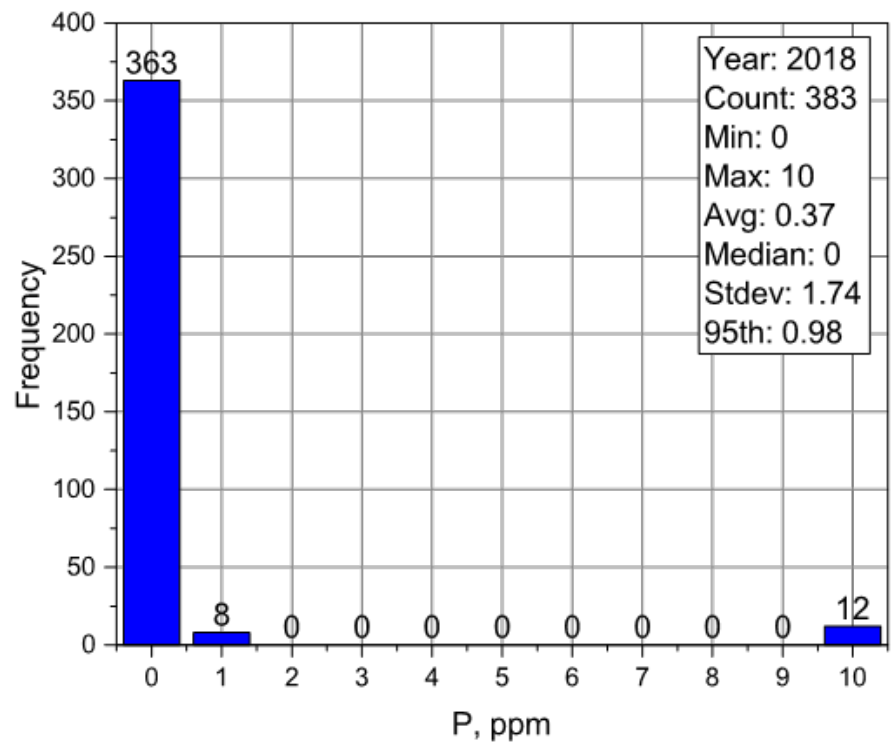

Figure 3. Phosphorus content for biodiesel samples, January-December 2018 


\subsection{Alcohol Control and Flash Point}

Figure 4 shows the average flash point was $153^{\circ} \mathrm{C}$, with a median of $161^{\circ} \mathrm{C}$. The $95^{\text {th }}$ percentile was $183^{\circ} \mathrm{C}$. The average methanol content (Figure 5) was 0.07 percent by mass (mass\%) and the median was 0.06 mass $\%$. The $95^{\text {th }}$ percentile was 0.141 mass $\%$.

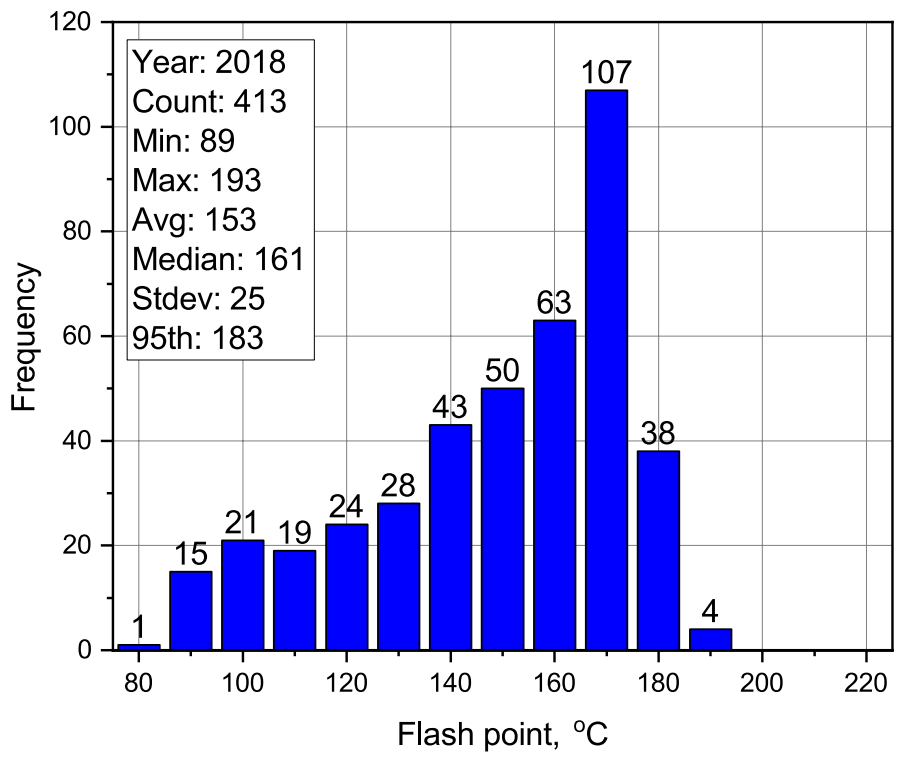

Figure 4. Flash point for biodiesel samples, January-December 2018

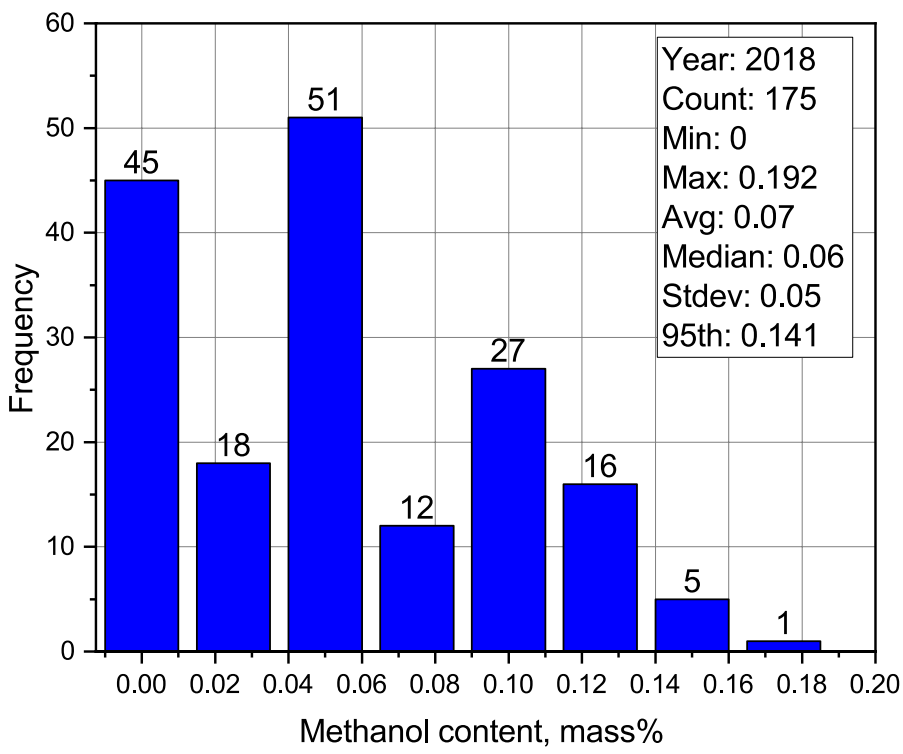

Figure 5. Methanol content for biodiesel samples, January-December 2018 


\subsection{Water and Sediment}

All producers reported their samples as clear and bright in 2018 and data are not presented graphically. The average water and sediment was 0.002 percent by volume (vol\%), the median was $0 \mathrm{vol} \%$, and the $95^{\text {th }}$ percentile was 0.010 vol\% (Figure 6).

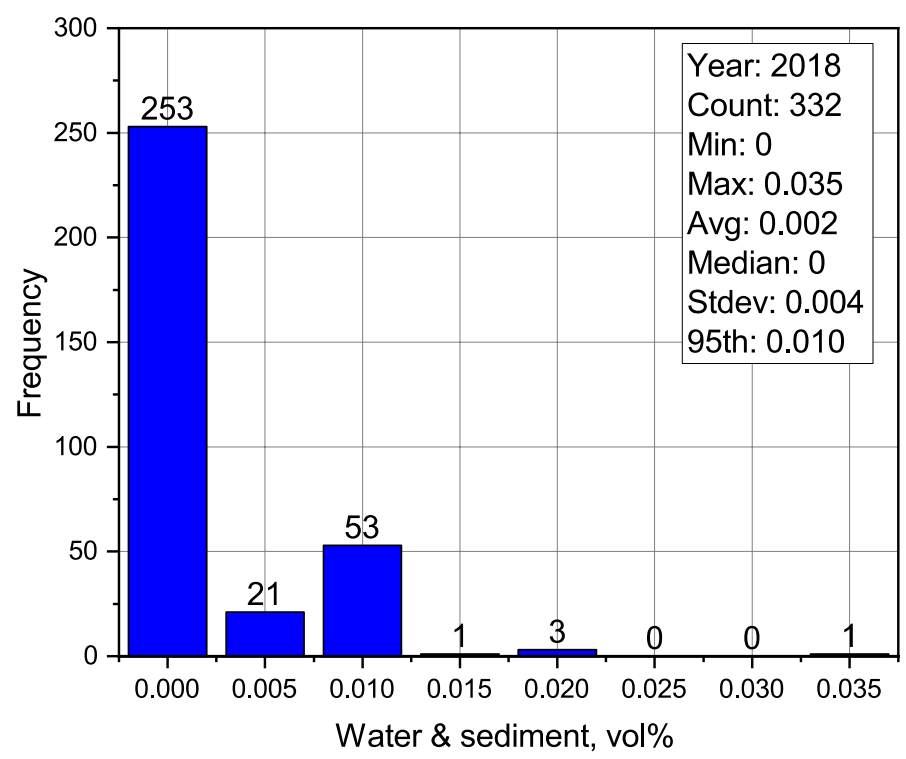

Figure 6. Water and sediment for biodiesel samples, January-December 2018

\subsection{Cloud Point}

The average, median, and $95^{\text {th }}$ percentile of the cloud point were $1.0^{\circ} \mathrm{C}, 0.0^{\circ} \mathrm{C}$, and $8.8^{\circ} \mathrm{C}$, respectively (Figure 7).

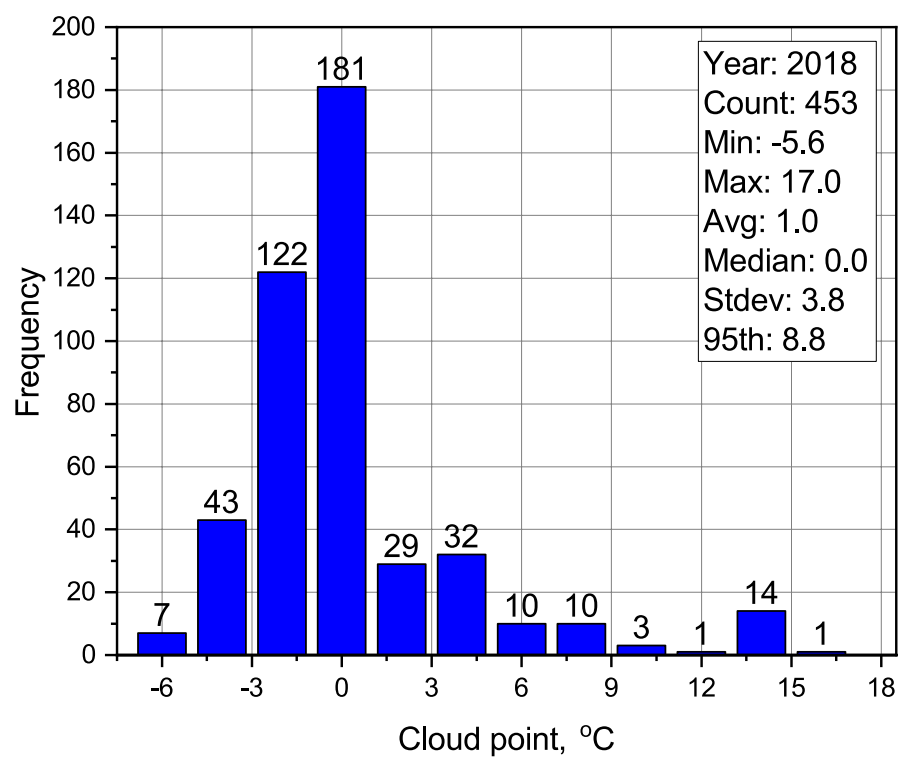

Figure 7. Cloud point for biodiesel samples, January-December 2018 


\subsection{Acid Number}

Figure 8 shows the acid number for the BQ-9000 producers in 2018. The average acid number was 0.27 milligram potassium hydroxide per gram $(\mathrm{mg} \mathrm{KOH} / \mathrm{g})$, the median was $0.27 \mathrm{mg}$ $\mathrm{KOH} / \mathrm{g}$ and the $95^{\text {th }}$ percentile was $0.43 \mathrm{mg} \mathrm{KOH} / \mathrm{g}$.

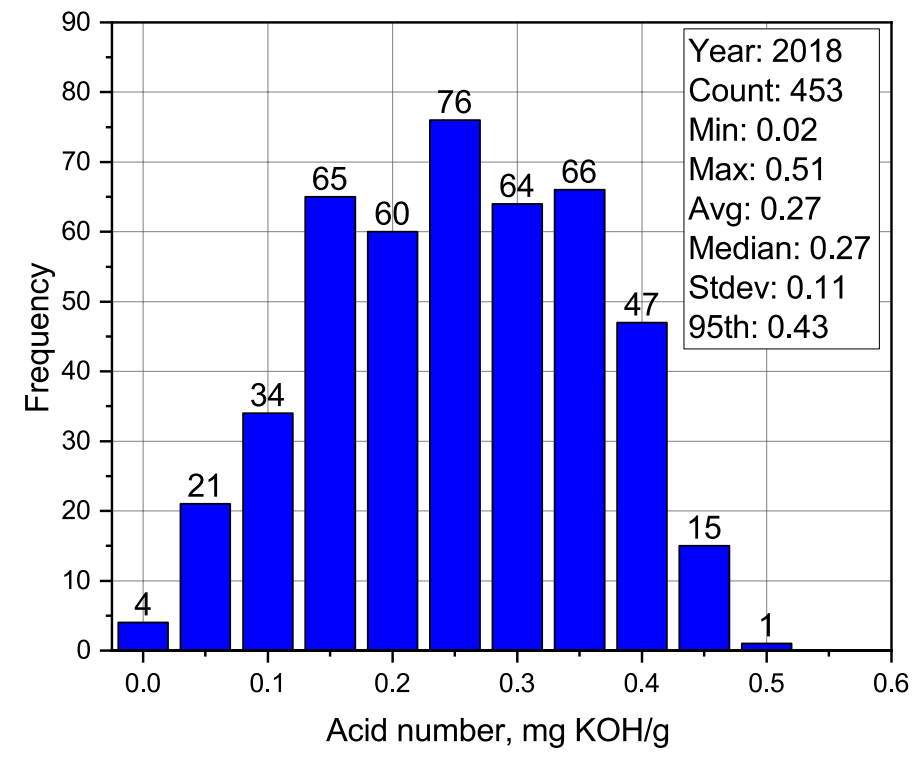

Figure 8. Acid number for biodiesel samples, January-December 2018

\subsection{Free and Total Glycerin}

Free glycerin results, shown in Figure 9, show an average of 0.006 mass\%, a median of 0.005 mass $\%$, and a $95^{\text {th }}$ percentile of 0.014 mass $\%$. The total glycerin for 2018 is shown in Figure 10. The average total glycerin was 0.093 mass $\%$ and the median was 0.099 mass $\%$. The $95^{\text {th }}$ percentile was 0.164 mass $\%$. 


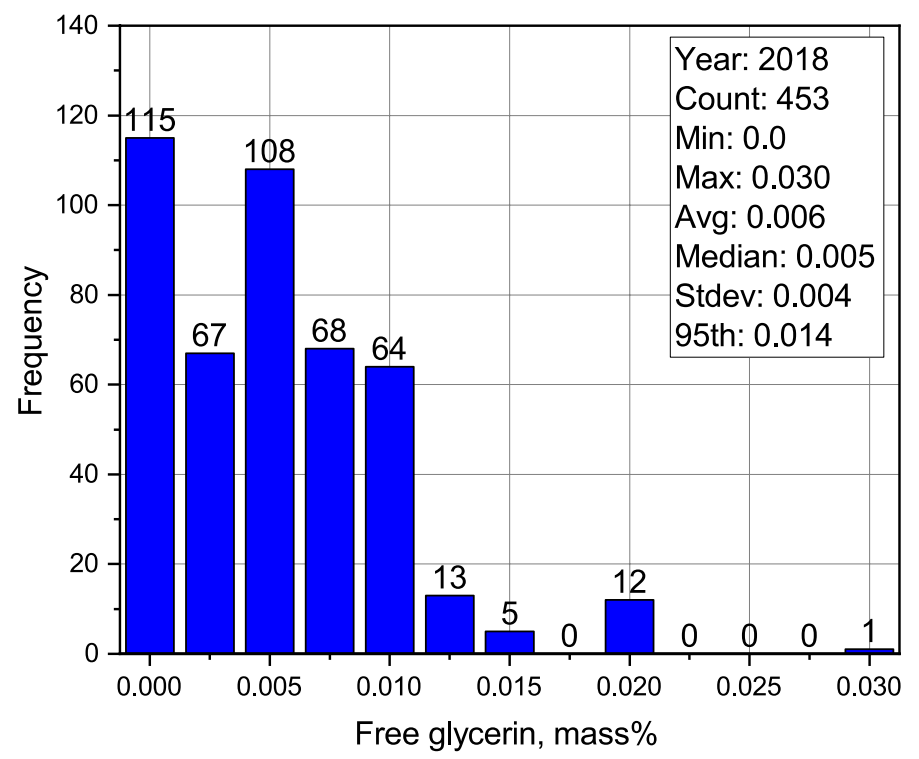

Figure 9. Free glycerin for biodiesel samples, January-December 2018

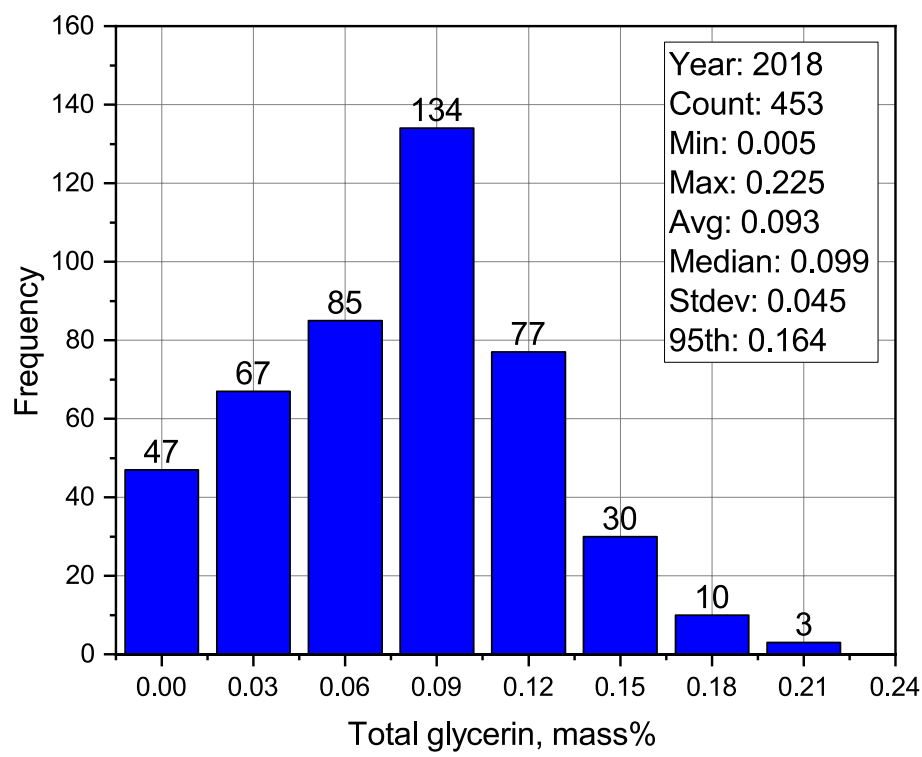

Figure 10. Total glycerin for biodiesel samples, January-December 2018 


\subsection{Monoglycerides}

Figure 11 shows monoglyceride content for the 2018 samples, with an average of 0.269 mass $\%$ and a $95^{\text {th }}$ percentile of 0.474 mass $\%$. The median monoglyceride content of these 2018 samples was 0.288 mass $\%$.

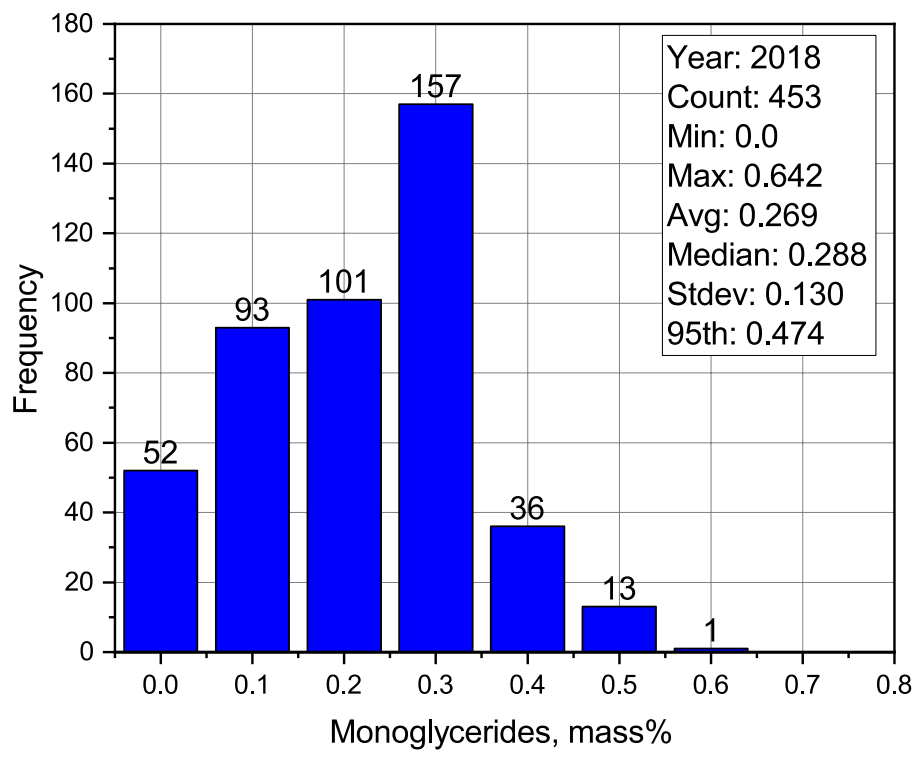

Figure 11. Monoglyceride content for biodiesel samples, January-December 2018

\subsection{Sulfur}

Figure 12 shows an average $\mathrm{S}$ content of $3.4 \mathrm{ppm}$, a median of $2.0 \mathrm{ppm}$, and a $95^{\text {th }}$ percentile of $10.9 \mathrm{ppm}$.

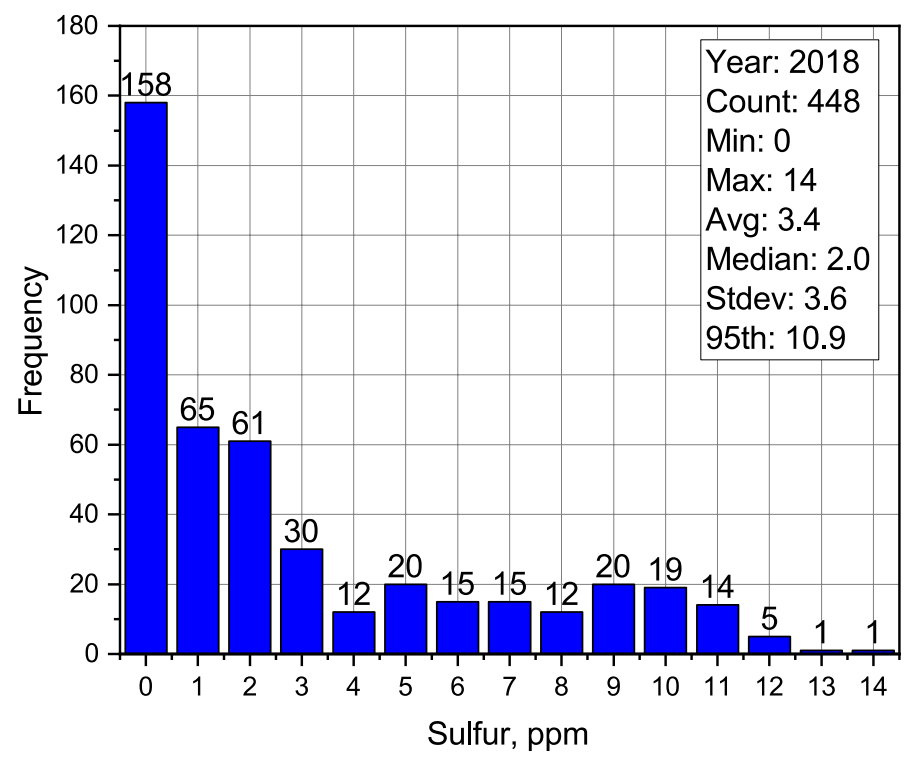

Figure 12. Sulfur content for biodiesel samples, January-December 2018 


\subsection{Oxidation Stability}

The oxidation stability of the biodiesel samples for calendar year 2018 is illustrated in Figure 13. The data analysis shows an average of 9.5 hours, a median of 8.7 hours, and a $95^{\text {th }}$ percentile of 14.2 hours.

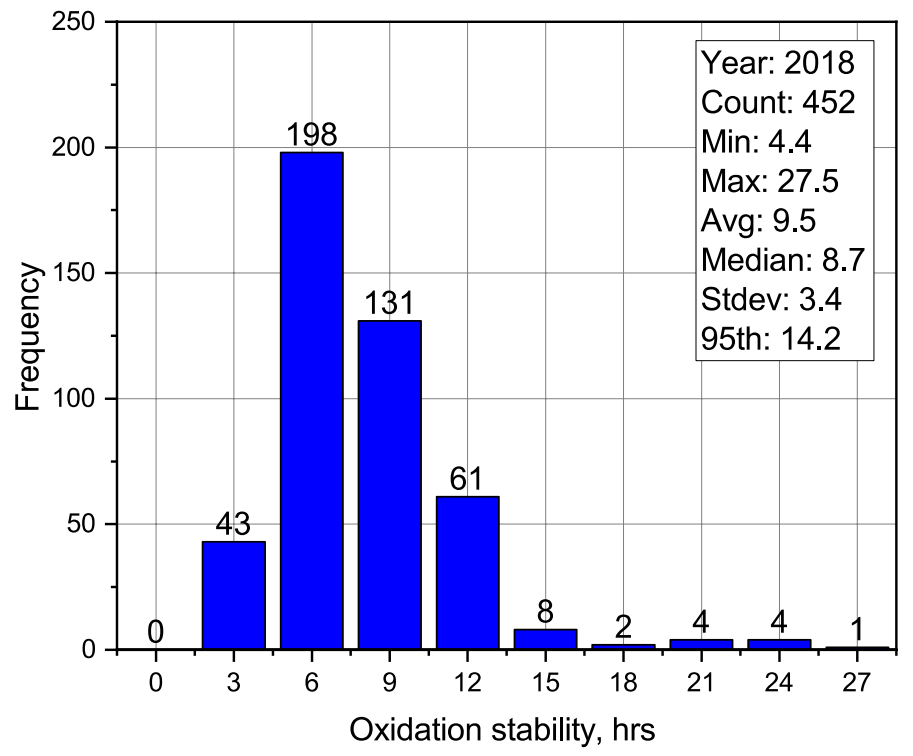

Figure 13. Oxidation stability for biodiesel samples, January-December 2018

\subsection{Cold Soak Filterability Test}

The average CSFT was 104 seconds (Figure 14). The $95^{\text {th }}$ percentile was 144 seconds and the median was 100 seconds. 


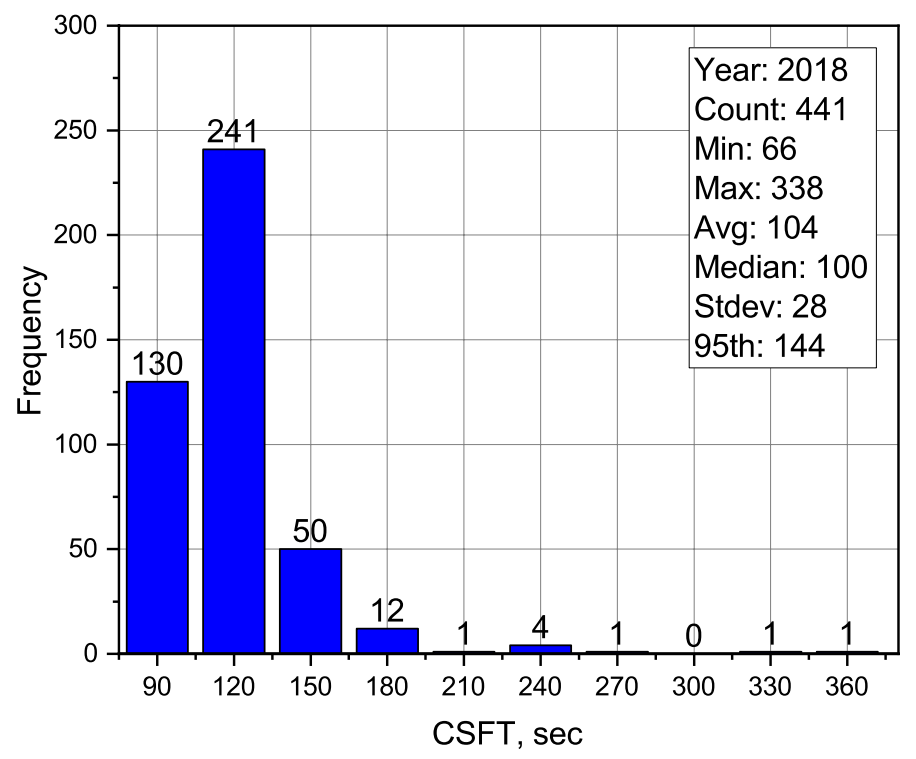

Figure 14. CSFT for biodiesel samples, January-December 2018 


\section{Summary}

This report covers monthly biodiesel quality data for calendar year 2018 from producers in the United States and Canada that participate in the BQ-9000 program. The data collection and handling were performed by a third-party team of Mr. Scott Fenwick, Mr. Steve Howell, and Dr. Richard Nelson. This team provided a firewall between NREL and the participants of the study to ensure any proprietary and confidential information was not released.

Similar to the 2017 report (Alleman 2020), this analysis includes the parameters summarized in Table 1. The analysis shows that biodiesel produced and sold in the United States routinely exceeded minimum specification requirements for flash point and oxidation stability. The samples fell below maximum specification limits for metals, alcohol control, acid number, free and total glycerin, sulfur, and CSFT.

Table 1. BQ-9000 Critical Parameter Summary Table, Calendar Year 2018

\begin{tabular}{|c|c|c|c|c|}
\hline $\begin{array}{l}\text { BQ-9000 } \\
\text { Parameter }\end{array}$ & Minimum & Maximum & Average & $\begin{array}{c}95^{\text {th }} \\
\text { Percentile }\end{array}$ \\
\hline $\mathrm{Na}+\mathrm{K}, \mathrm{ppm}$ & 0 & 4.5 & 0.688 & 2.20 \\
\hline $\mathrm{Ca}+\mathrm{Mg}, \mathrm{ppm}$ & 0 & 4.4 & 0.313 & 2.00 \\
\hline $\mathrm{P}, \mathrm{ppm}$ & 0 & 10 & 0.371 & 0.98 \\
\hline Flash Point, ${ }^{\circ} \mathrm{C}$ & 89 & 193 & 153 & 183 \\
\hline $\begin{array}{c}\text { Alcohol Control, } \\
\text { mass } \%\end{array}$ & 0 & 0.192 & 0.066 & 0.141 \\
\hline $\begin{array}{c}\text { Water and } \\
\text { Sediment, vol\% }\end{array}$ & 0 & 0.035 & 0.002 & 0.010 \\
\hline Cloud Point, ${ }^{\circ} \mathrm{C}$ & -5.6 & 17 & 1 & 8.8 \\
\hline $\begin{array}{l}\text { Acid Number, mg } \\
\mathrm{KOH} / \mathrm{g}\end{array}$ & 0.02 & 0.51 & 0.27 & 0.43 \\
\hline $\begin{array}{c}\text { Free Glycerin, } \\
\text { mass } \%\end{array}$ & 0 & 0.030 & 0.006 & 0.014 \\
\hline $\begin{array}{l}\text { Total Glycerin, } \\
\text { mass } \%\end{array}$ & 0.005 & 0.225 & 0.093 & 0.164 \\
\hline $\begin{array}{c}\text { Monoglycerides, } \\
\text { mass } \%\end{array}$ & 0 & 0.642 & 0.269 & 0.474 \\
\hline Sulfur, ppm & 0 & 14 & 3.4 & 10.9 \\
\hline $\begin{array}{l}\text { Oxidation } \\
\text { Stability, hr. }\end{array}$ & 4.4 & 27.5 & 9.5 & 14.2 \\
\hline $\begin{array}{c}\text { Cold Soak } \\
\text { Filterability Test, } \\
\text { sec }\end{array}$ & 66 & 338 & 104 & 144 \\
\hline
\end{tabular}




\section{References}

Alleman, T.L. 2020. Assessment of BQ-9000 Biodiesel Properties for 2017. Golden, CO: National Renewable Energy Laboratory. NREL TP-5400-75795.

ASTM International. 2018. ASTM D6751, Standard Specification Biodiesel Fuel Blend Stock (B100) for Middle Distillate Fuels. West Conshohocken, PA: ASTM International. http://doi.org/10.1520/D6751-18.

Dietrich, Maren. 2017. Biodiesel Quality in Germany. Sampling Results of Biodiesel Producers and Warehouse Operators of Association Quality Management Biodiesel (AGQM). Neusaess, Germany: ASG Analytik-Service GmbH. https://www.agqm-biodiesel.com/application/files/ 5515/2464/7963/QualityReport 2017.pdf. 


\section{Appendix}

The appendix provides informational data only for biodiesel produced in the United States and Canada in 2018. The figures include all data provided and have assigned any data reported as "greater than" or "less than" the value listed. For example, if phosphorus was reported as " $<1$ ppm," the data point was assumed to be $1 \mathrm{ppm}$ and was included in the appendix analysis. Because of this unique data treatment, no statistics have been computed on the data. 


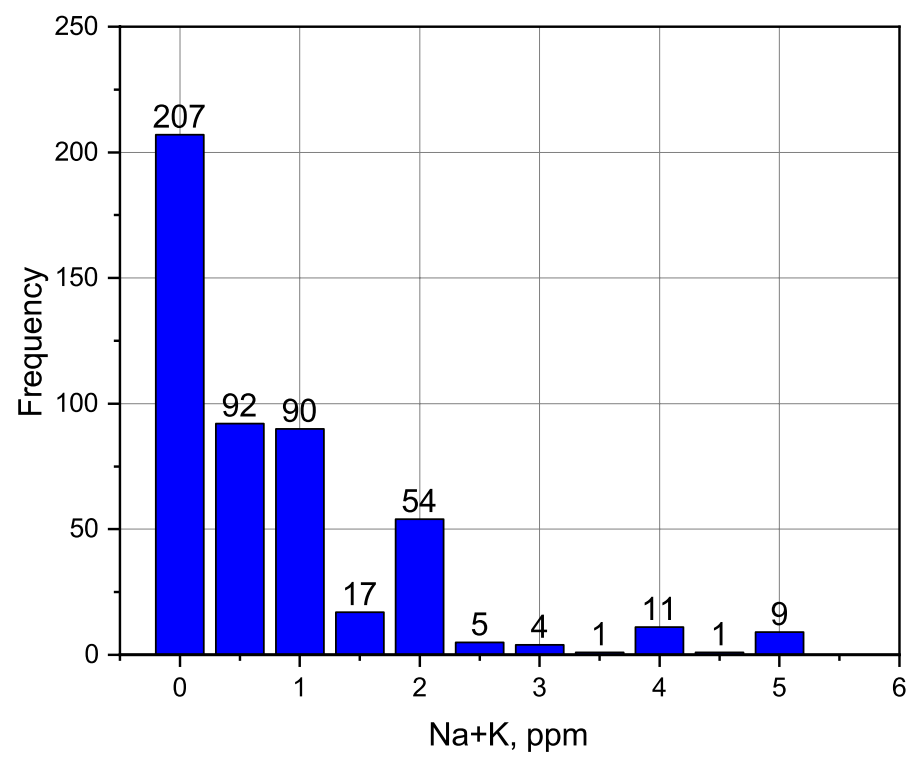

Figure A-1. All data analysis of sodium and potassium for B100 samples produced JanuaryDecember 2018.

Data reported as "greater than X" or "less than X" are assumed to have the value of X.

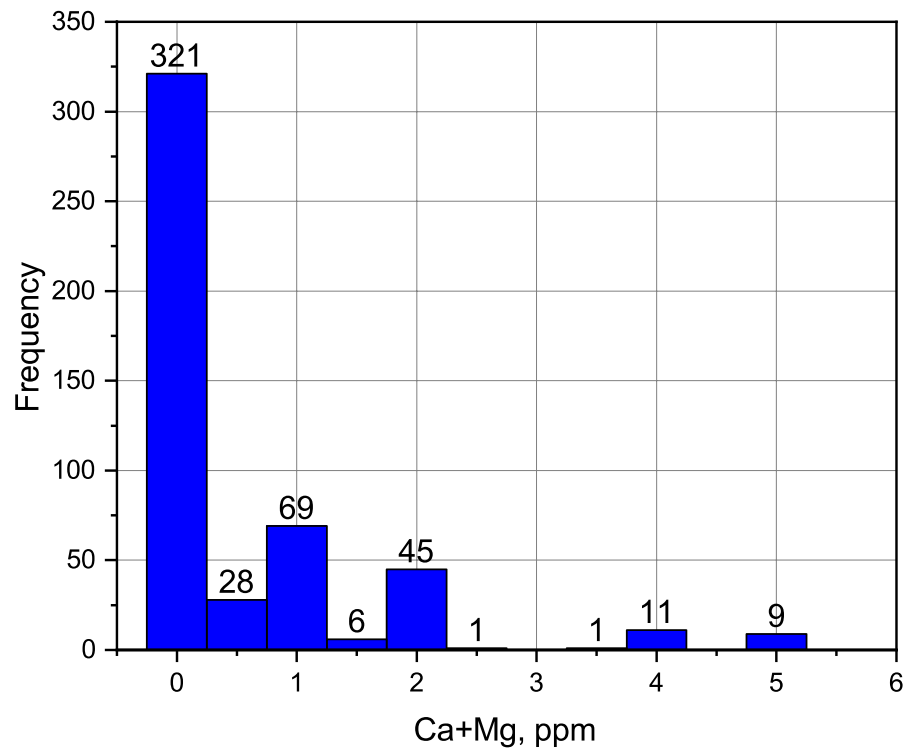

Figure A-2. All data analysis of calcium and magnesium for B100 samples produced JanuaryDecember 2018.

Data reported as "greater than X" or "less than X" are assumed to have the value of X. 


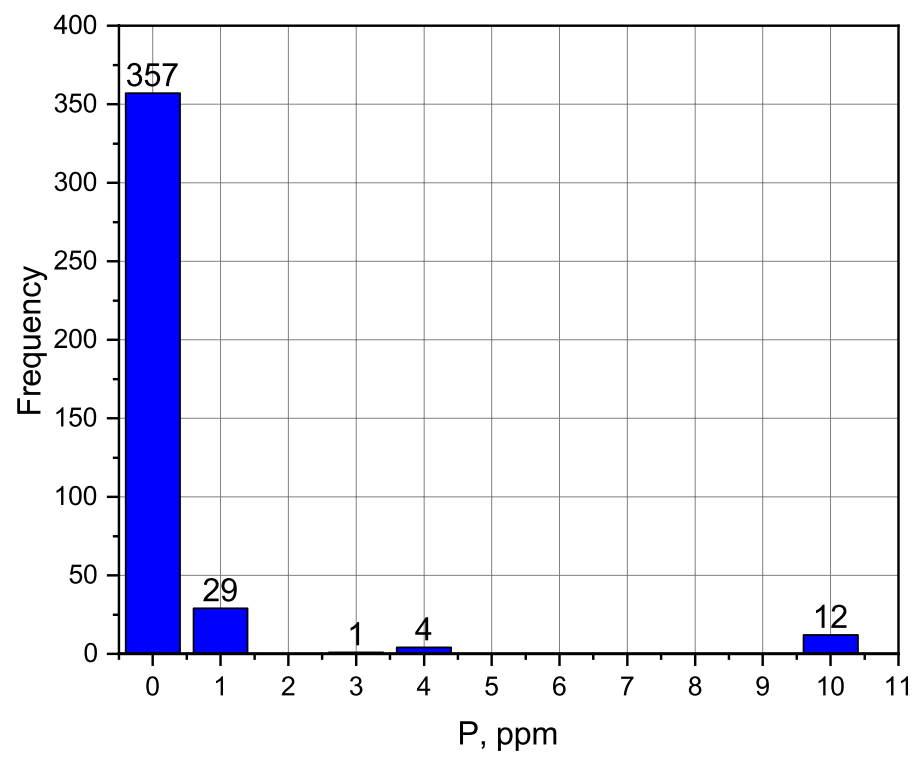

Figure A-3. All data analysis of phosphorus for B100 samples produced January-December 2018.

Data reported as "greater than X" or "less than X" are assumed to have the value of X.

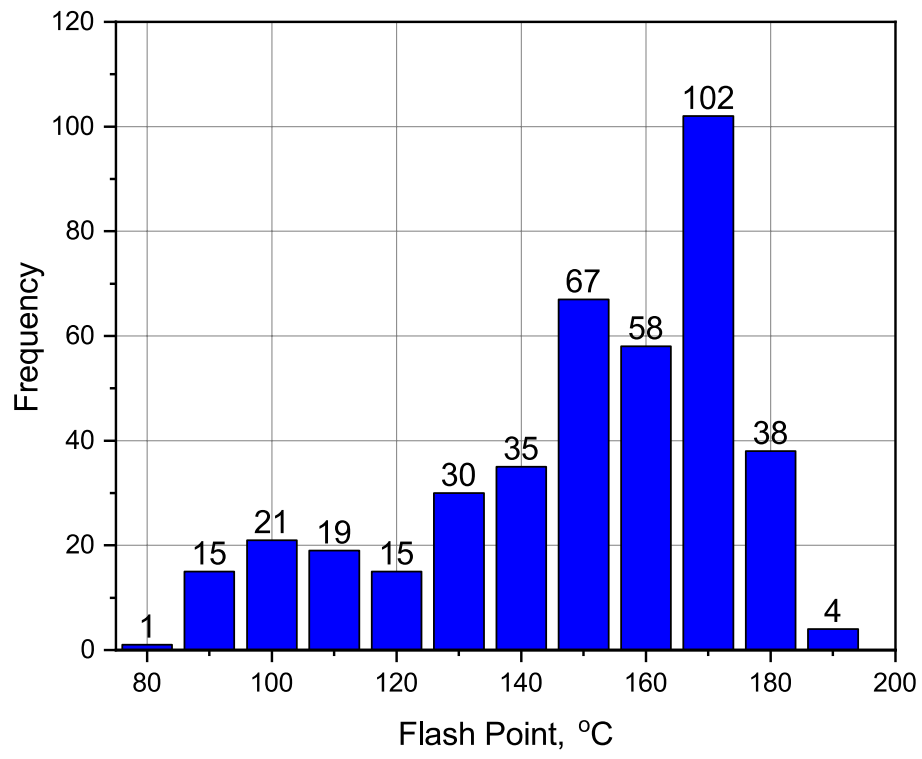

Figure A-4. All data analysis of flash point for B100 samples produced January-December 2018. Data reported as "greater than X" or "less than X" are assumed to have the value of X. 


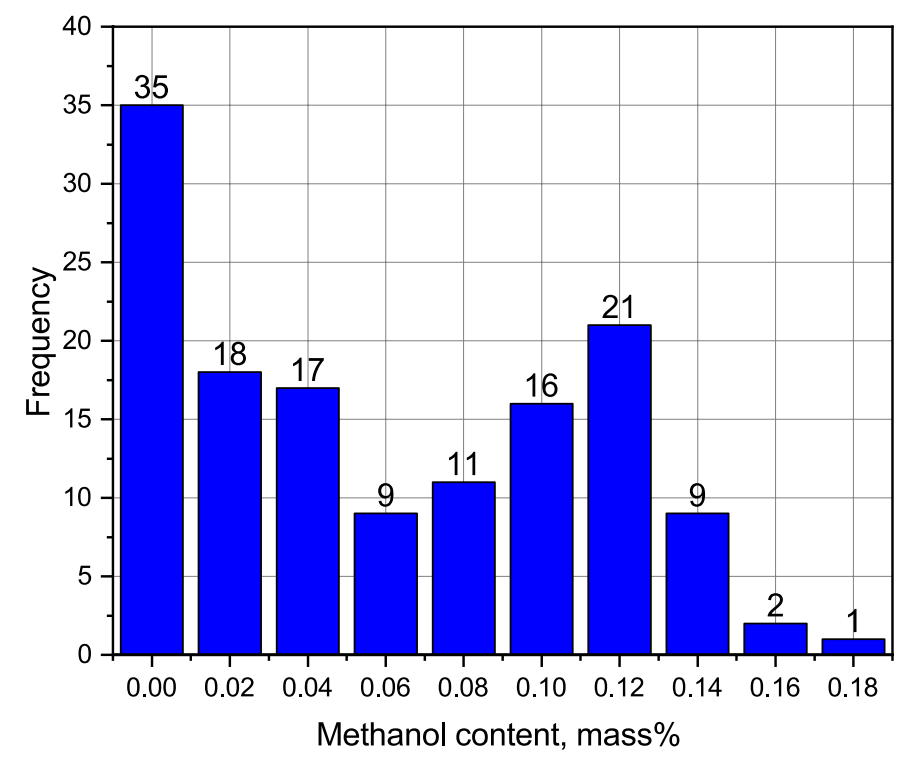

Figure A-5. All data analysis of alcohol control for B100 samples produced January-December 2018.

Data reported as "greater than X" or "less than X" are assumed to have the value of X.

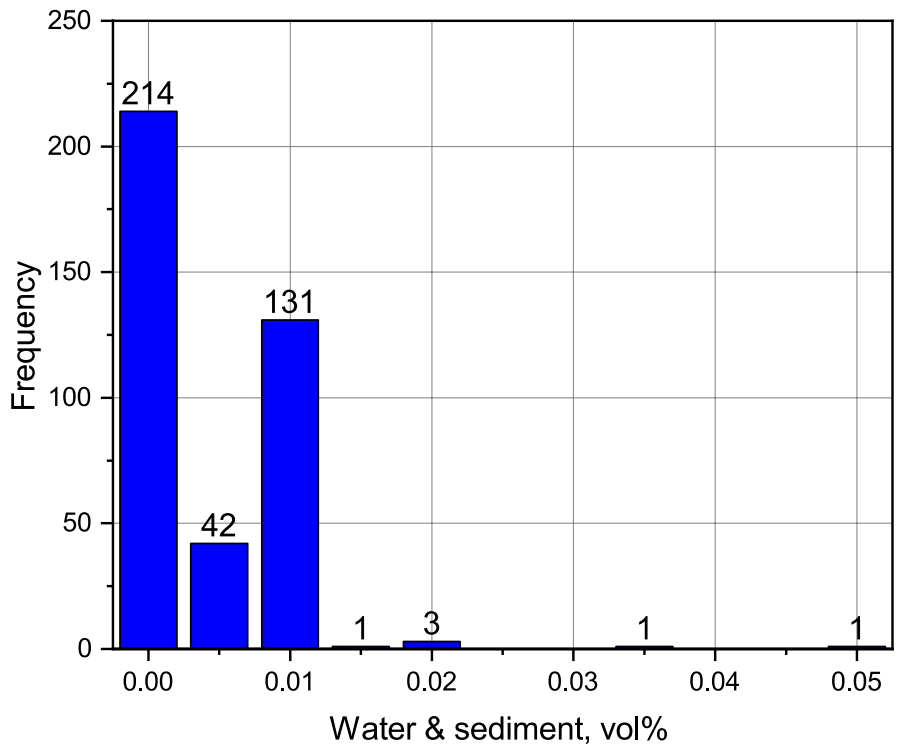

Figure A-6. All data analysis of water and sediment for B100 samples produced JanuaryDecember 2018.

Data reported as "greater than X" or "less than X" are assumed to have the value of X. 


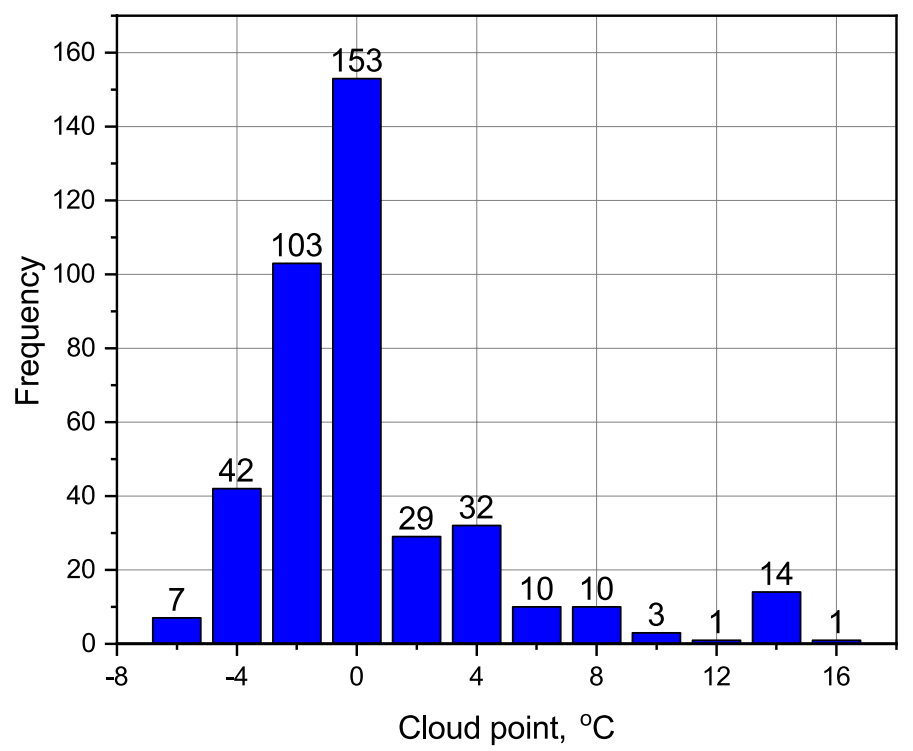

Figure A-7. All data analysis of cloud point for B100 samples produced January-December 2018.

Data reported as "greater than X" or "less than X" are assumed to have the value of X.

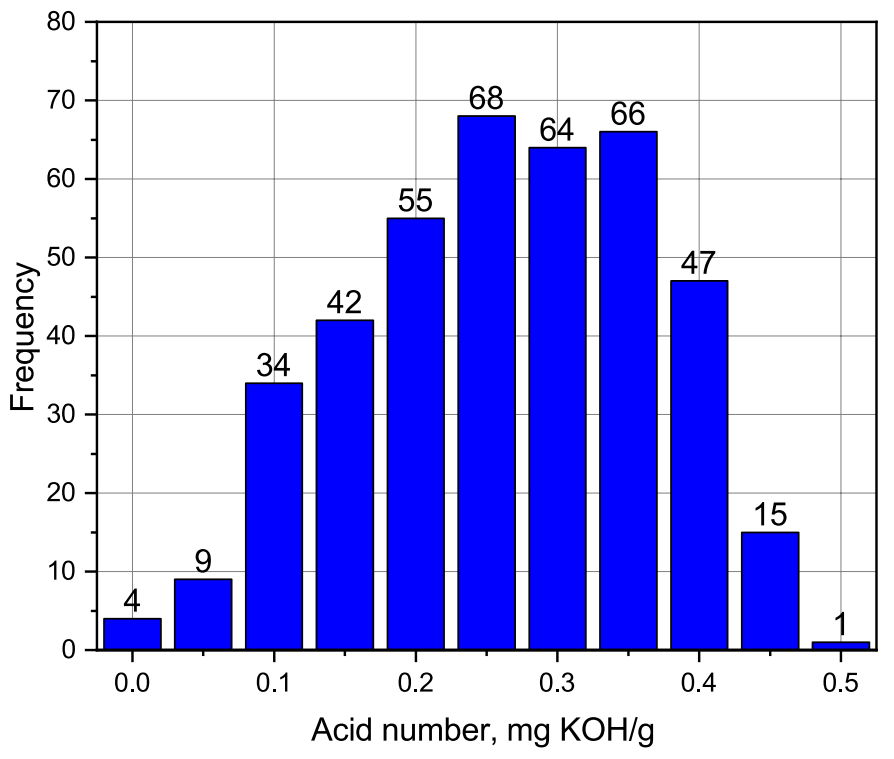

Figure A-8. All data analysis of acid number for B100 samples produced January-December 2018. Data reported as "greater than X" or "less than X" are assumed to have the value of X. 


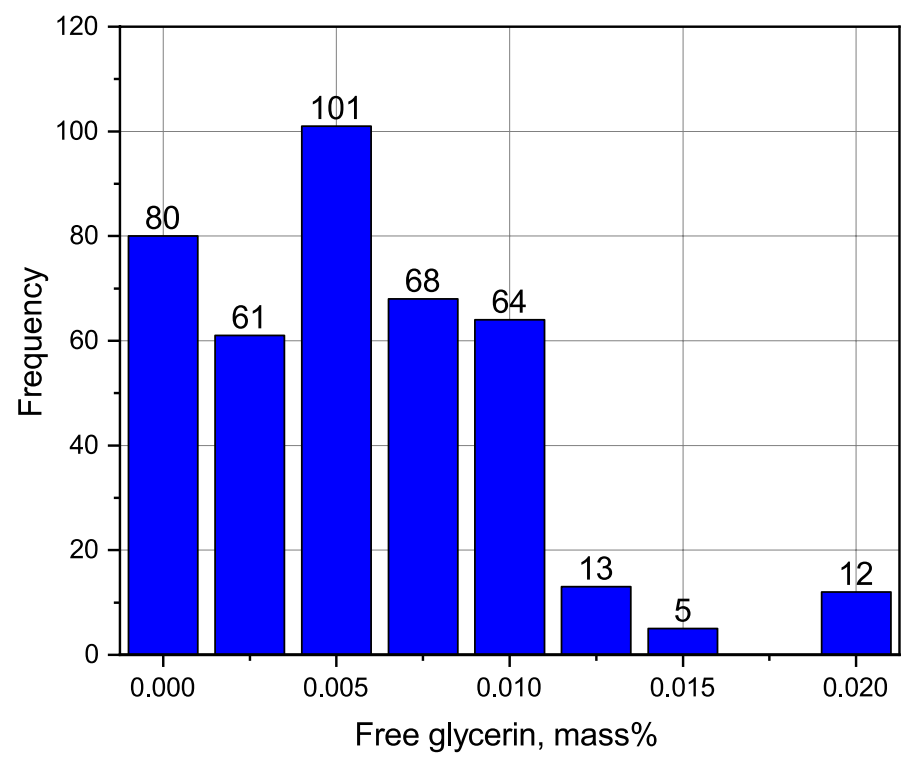

Figure A-9. All data analysis of free glycerin for B100 samples produced January-December 2018. Data reported as "greater than X" or "less than X" are assumed to have the value of X.

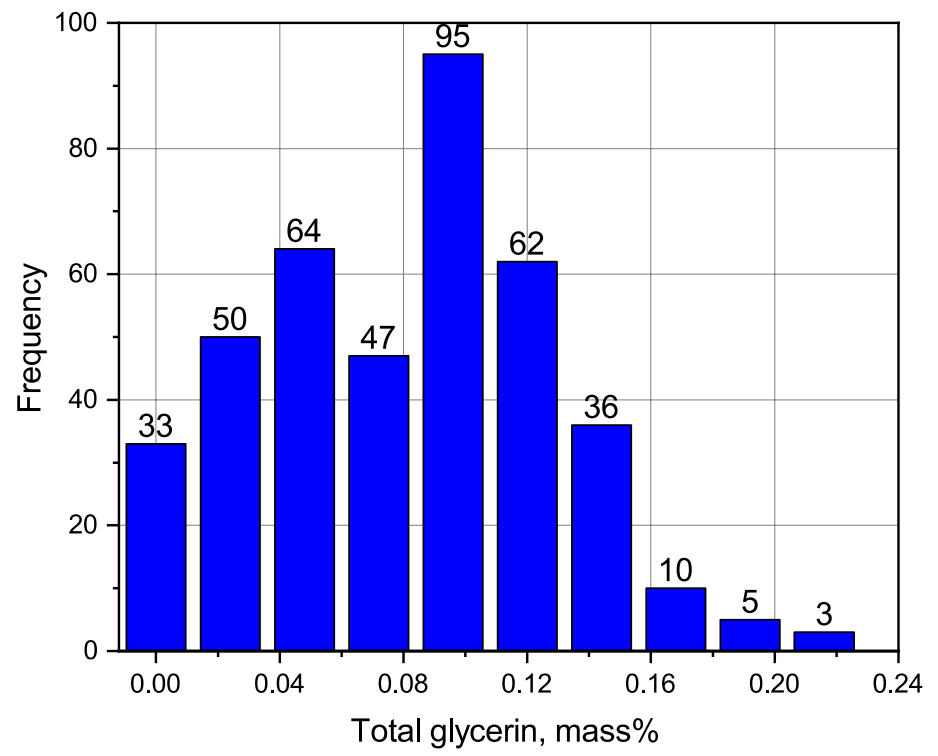

Figure A-10. All data analysis of total glycerin for B100 samples produced January-December 2018.

Data reported as "greater than X" or "less than X" are assumed to have the value of X. 


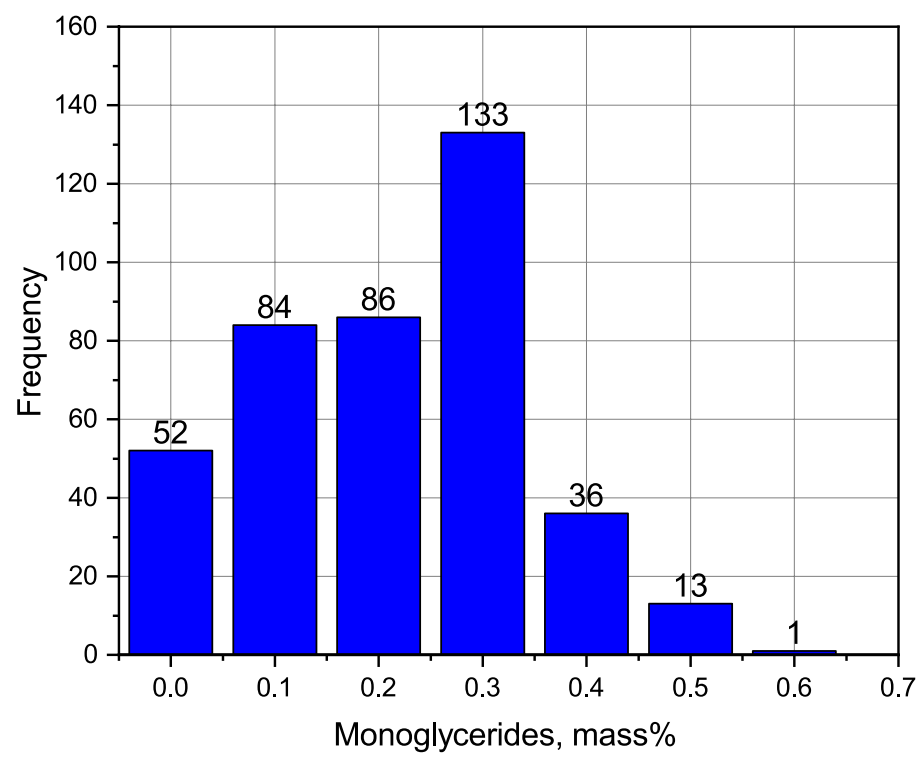

Figure A-11. All data analysis of monoglycerides for B100 samples produced January-December 2018.

Data reported as "greater than X" or "less than X" are assumed to have the value of X.

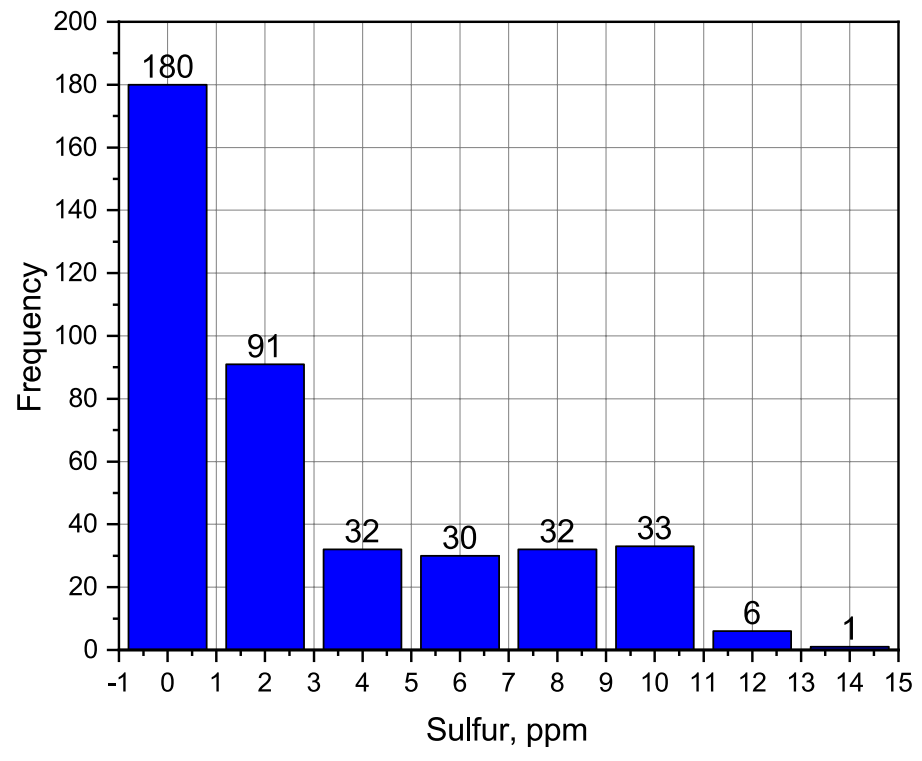

Figure A-12. All data analysis of sulfur for B100 samples produced January-December 2018.

Data reported as "greater than X" or "less than X" are assumed to have the value of X. 


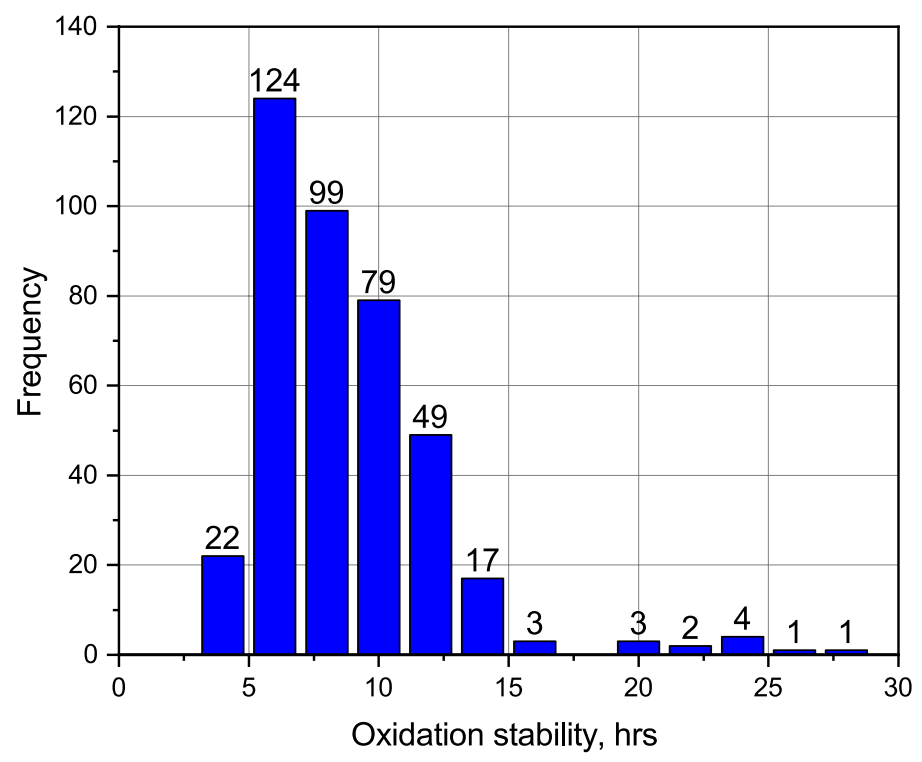

Figure A-13. All data analysis of oxidation stability for B100 samples produced January-December 2018.

Data reported as "greater than X" or "less than X" are assumed to have the value of X.

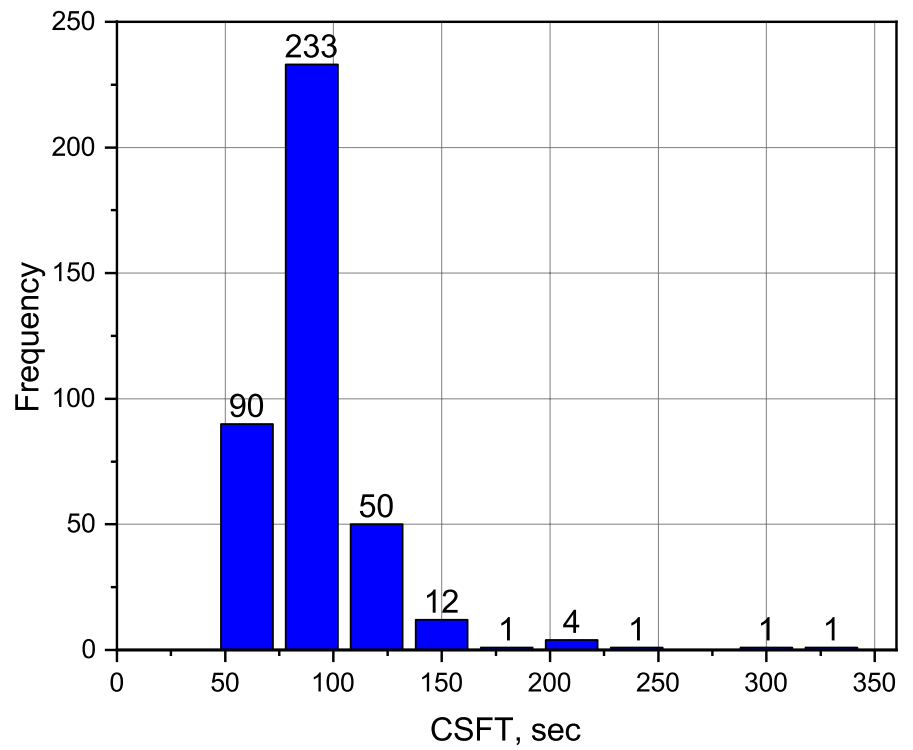

Figure A-14. All data analysis of CSFT for B100 samples produced January-December 2018. Data reported as "greater than X" or "less than X" are assumed to have the value of X. 